\title{
Bioelectricity Production Using Microbial Fuel Cell-a Review
}

\author{
Kasirajan Kasipandian ${ }^{1}$, Saigeetha S. ${ }^{2}$, Antony V. Samrot ${ }^{3 *}{ }^{*}$ (D), Abirami S. ${ }^{4}$, R. Emilin Renitta ${ }^{5}$, \\ Dhiva S. ${ }^{6}$
}

1 Department of Electrical and Electronics Engineering, Faculty of Engineering and Built Environment, MAHSA University, Jenjarom, Selangor - 42610, Malaysia

2 Department of Biotechnology, School of Bio and Chemical Engineering, Sathyabama Institute of Science and Technology, Shollinganallur, Rajiv Gandhi sSalai, Chennai, Tamil Nadu, 600119, India

3 Department of Bioscience, Faculty of Medicine, Bioscience and Nursing, MAHSA University, Jalan SP2, Bandar Saujana Putra, 42610, Jenjarom, Selangor, Malaysia

4 Department of Microbiology, Kamaraj College, Thoothukudi, India

5 Department of Food Processing, Karunya Institute of Technology and Science, Coimbatore, Tamil Nadu, India

6 Department of Microbiology, Sree Narayana College, Alathur, Palakkad, Kerala 678682, India

* Correspondence: antonysamrot@gmail.com;

Scopus Author ID 36100751800

Received: 6.08.2020; Revised: 9.09.2020; Accepted: 11.09.2020; Published: 13.09.2020

\begin{abstract}
This paper summarised different methods used for the electrical power generation using microorganisms in MFC. In the past decade, Microbial Fuel Cells (MFC) attracted many researchers due to their ability to convert organic waste into electric currents by the usage of microorganisms. It has been developing as a great source of renewable energy. This device makes use of simple cathode and anode compartments and a separating membrane. This can be efficiently used for power generations and wastewater treatments. Microbial electrolysis cell (MEC), a type of MFC is also used in generating Hydrogen energy from various biological matters. The performance of MFC totally depends upon the nature of microorganisms, electrodes selected, and the separating membarane used. MFCs serve as a sustainable and alternate energy source to reduce the pollution caused by industrialization. In this review, a detailed explanation about MFC and different ways of generating bioelectricity and hydrogen from wastewater treatment are explained.
\end{abstract}

Keywords: Microbial Fuel Cell; types; bioeletricity; waste water treatment

(C) 2020 by the authors. This article is an open-access article distributed under the terms and conditions of the Creative Commons Attribution (CC BY) license (https://creativecommons.org/licenses/by/4.0/).

\section{Introduction}

Nowadays, there is a huge demand for electricity around the globe. Due to the diminishing and polluting nature of fossil fuels, renewable energy sources get a huge attraction. Hydrogen combustion and Microbial fuel cell (MFC) are suitable for generating electric currents without emitting any toxic gases and water as byproduct [1]. MFCs uses bacteria as the catalysts to oxidize inorganic substance such as non-carbon materials like Sulfur compound etc. and organic matter such as muds, food wastes, vegetable wastes, fruit wastes, plant leaves, grass pieces to produce electricity. Some researchers proved that hydrogen could be produced efficiently in MFC, which is used for the supply of electricity and purification of water in the system. To eliminate the carbon emissions, hydrogen can be used as it is persistent with both combustion and electrochemical process for energy combustion. There are a different kinds of methods available to generate hydrogen, and some of the examples are electrolysis of water 
and microbial generation [2]. Biohydrogen can be produced in two different ways. One among them is photosynthetic organisms produce biohydrogen with the help of light energy, and the other is anaerobic bacteria produces biohydrogen by dark fermentation [3]. The power generations can be increased through various methods in MFCs as the electricity is generated from the waste materials. Factors affecting the power generation are the types of electrode materials, the dimension of electrodes, proton exchange membranes, etc. Power density was increased through a suitable experiment on ammonium treated carbon electrodes. In this attempt, ammonium treated anode depends upon two different factors based on the improvement of power generation such as reactor startup increase the adhesion of bacteria and increased efficiency of electron transfer to the surface by bacteria. The electron transfer was improved due to the ammonium treatment [4]. Electrodes play an important role in MFC, but its performance was affected due to fluctuations in the electron transfer between microbes and electrodes [5]. The ammonia gas treatment conducted by Cheng et al. [4] showed increased surface charge which could be due to high-temperature treatment of carbon cloth electrode. Liu et al. [6] demonstrated that the power density was increased with increasing the ionic strength of the solution and decreased when the distance between the electrodes in a single chamber MFC with air as cathode. Other anode materials used in different studies are carbon paper [6], graphite granules [7], graphite felt [8], and reticulated vitreous carbon [9], Carbon brush, stainless steel etc. [10]. To avoid the corrosion of electrodes due to moisture, the electrodes must be selected carefully. Moreover, some other factors like active surface area, biocompatibility, nature of electrode surface, high conductivity, electron collectors that can accommodate a maximum number of bacteria, and metals capable of transferring electrons over long distances influence the performance of MFC [11]. To get high coulombic yield kim et al.[12] conducted cyclic voltammetric studies by using a high concentration of bacteria and a large surface area electrode. electrochemical activities were shown by anaerobically grown cells of Shewanella putrefaciens MR-1, IR-1, and SR-21. In another experiment to generate electricity Rabaey et al.[13] utilized different glucose dosage as a carbon source for a mixed bacteria culture in an MFC. The authors concluded that the rates could be improved by selecting adapted anodophylic consortia. Mohan et al.[14] also used mixed consortia for electrical power generation in a different environment. They worked separately with aerated catholyte and ferricyanide catholyte for power generation and found that ferricyanide catholyte produced more power than aerated catholyte. Liu et al.[15] conducted an experiment to reduce the cost and to increase the energy output with or without the Proton exchange membrane (PEM). In this experiment, they used bacteria living in the domestic wastewater as biocatalyst, glucose, and wastewater as substrates, and obtained better results for experimental setup without PEM. Shahi et al. [16] performed a study by comparing Nafion and agar salt bridge MFC using wastewater as a substrate. In their study, they found that Nafion membrane-based MFC produced more electricity than agar bridge MFC. Using the same concept Mittapalli et al [17] generated electricity using Exiguobacterium sp in a mediatorless MFC having kitchen waste and carboxymethyl as substrates. They found that more electricity was produced in Nafion membrane fitted MFC. Likewise, more studies on wastewater research have been performed by many researchers with dairy wastewater [18]. Prakash et al.[19] developed an experimental setup to generate electricity of $0.4 \mathrm{~V}$ from dairy wastewater in two-chambered MFC. $0.45 \mathrm{mV}$ electricity was produced from dairy waste water and reported that maximum electricity prodution depends upon electrode size [20]. 


\section{Types of MFCs and electricity generated}

\subsection{Single chamber $M F C$.}

A single-chambered MFC consists of an air cathode and an anode with or without separating membrane (Fig. 1). If the separating membrane is present, it is usually attached to the cathode [21]. In single-chambered MFC the electrons and protons present in the anode due to the oxidation reaction of organic matters by microorganisms are transferred to the cathode by PEM or external circuit [22]. Cathode performance influenced the maximum power density of the air-driven Microbial Fuel cells. Cathode plays an important role in this type because in the neutral $\mathrm{pH}$ medium, there exists a poor oxidation-reduction reaction [6]. It has been reported that the air cathodes used in Single chamber MFC have low liquid volume [23] and using small air cathode, some effects towards power output were shown as it has a difference in the electrode spacing, nature of PEM, and nature of inoculum [24, 25, 26]. In a tubular single chambered continuous MFC, where carbon and granular graphite used a cathode and anode produced maximum power around $65 \pm 5 \mathrm{~W} / \mathrm{m}^{3}$ and $188 \pm 7 \mathrm{~mA} / \mathrm{m}^{3}$ respectively [27]. A tubular MFC was developed for Cr (VI) reduction in biocathode where graphite brush \& graphite granule as anode and cathode and produced a maximum power density of $6.4 \mathrm{~W} / \mathrm{m}^{3}$ [28]. A single chamber MFC with graphene-coated electrodes as both anode and cathode produced a volumetric peak power output of $3.51 \pm 0.50 \mathrm{~W} \mathrm{~m}^{-3}$ [29]. Single chambered MFC with graphite fiber brush as anode and air cathode produced a maximum power density of about $1460 \pm 10 \mathrm{~mW} \mathrm{~m}-2$ [30]. The SCMFC was designed by keeping carbon felt as anode and carbon cloth as cathode; maximum power density of $8.3 \pm 0.2 \mathrm{~W} / \mathrm{m} 340$ was observed [31]. MFC with carbon paper with platinum as cathode and carbon paper as anode gave a maximum power density of $488 \pm 12 \mathrm{~mW} / \mathrm{m}^{2}$ [32].

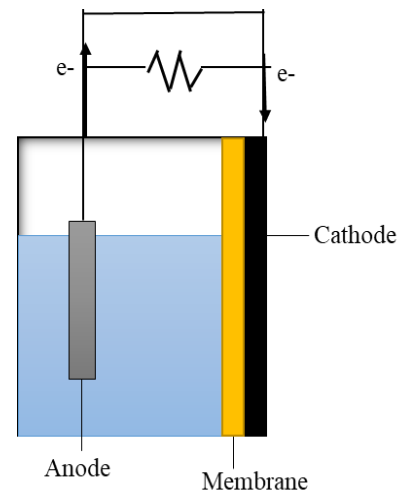

Figure 1. Single chambered MFC.

\subsection{Two-chamber $M F C$.}

Microbial Fuel Cells are most commonly used as two-chambered system (Fig. 2). The two containers MFC includes an anaerobic anode and an aerated cathode. Both the electrode chambers were joined using a close-fitting proton exchange membrane (PEM) or an salt bridge. Bacteria grow anaerobically, forms a biofilm and adhere to the anode, where the other chamber is maintained with aerobic conditions by supplying water and air to cathode [33, 34, 35]. In this system, the cations other than protons travel from cathode to anode through PEM results in the drop down of $\mathrm{pH}$ in the anode region and increase of $\mathrm{pH}$ in the cathode region, which ultimately leads to the reduction of cathode potential and it is considered to be the limiting step [36]. Various factors, such as the nature of electrodes, $\mathrm{pH}$, external load, flow rate, play an 
important role in controlling the performance of MFC [37] and they are widely used in the production of electricity [38]. In an experimental setup where rough graphite plate was used as a cathode and soft graphite plate as an anode having the waste water as source and a maximum current density was produced upto $313 \mathrm{~mA} / \mathrm{m}^{2}$ [39]. A carbon cloth with four poly-PTFE diffusion layers were used as a cathode, and heat treated carbon brush was used as an anode, which generated a maximum current density of $0.49 \mathrm{~A} / \mathrm{m}^{2}$. The same setup with different effluent generated maximum power density and maximum current density of $554 \mathrm{~mW} / \mathrm{m}^{2}$ and $1.0 \mathrm{~A} / \mathrm{m}^{2}$, respectively. [40]. A mixture of denitrifying and anaerobic mixed cultures enriched with $\mathrm{Cr}(\mathrm{VI})$ and graphite plate electrodes for both anode and cathodes were used which produced current density and power density were around $123.4 \mathrm{~mA} / \mathrm{m}^{2}$ and $55.5 \mathrm{~mW} / \mathrm{m}^{2}$ respectively [41]. During biomineralized reduction process of $\mathrm{MnO}_{2}$, it produced a maximum power density of $126.7 \pm 31.5 \mathrm{~mW} / \mathrm{m}^{2}$, and a lower power density of $3.9 \pm 0.7 \mathrm{~mW} / \mathrm{m}^{2}$ was produced while oxygen reduction where reticulated vitreous carbon was used as both anode and cathode in the setup [42].

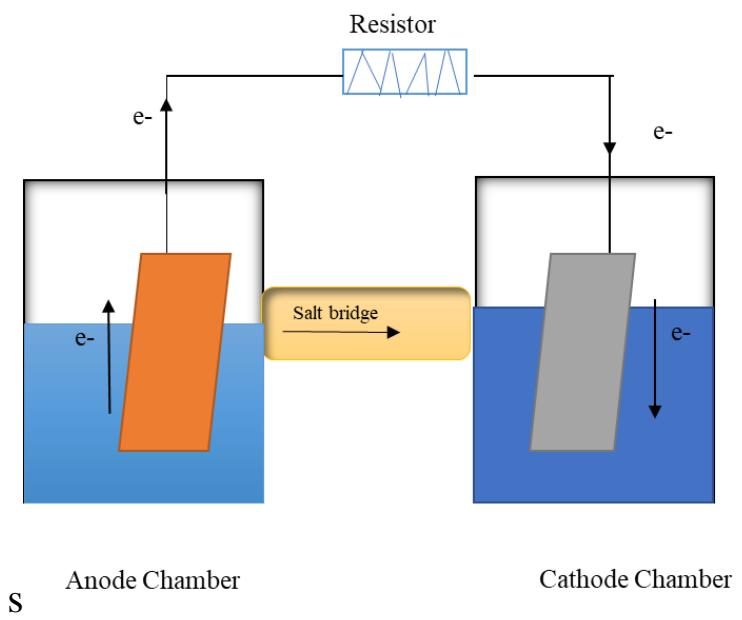

Figure 2. Two-Chamber MFC.

\subsection{Multi container MFC.}

It is a three-chambered design consist of an oxic cathode and anoxic cathode, and one anode (Fig. 3). It a simultaneously perform three electrochemical reactions at a single time. The recent application of this type of MFC is it can perform denitrification, sulfide removal, and electricity generation simultaneously. Each chamber is separated by a desalination unit [43]. The major advantages of multi container MFC are multifunctions can be done at a time. Graphite fiber brush was intertwined by two titanium wires was used as anode and cathode. The stable current prevailing in the multiple chambers MFC results in the flow of multiple ions [44]. The generated peak power output was observed as $13.2 \pm 1.7 \mathrm{~W} / \mathrm{m}^{3}$ [45]. Samsudeen et al. [46] designed a multi container MFC with a single cathode chamber and 4 anode chambers. The chambers were discredited by a membrane to overcome a longer period for water treatment and sustainable energy production. If any of the anode chambers failed, the sustainable energy was retained by the help of other chambers. In this research with Graphite electrode, Potassium ferricyanide catholyte, and consuming wastewater of concentration $8720 \mathrm{mg}$ COD / L, A maximum power density of $135.4 \mathrm{~mW} / \mathrm{m}^{2}$ was attained. More studies on multiple Chamber MFC are still needed for better understanding. 


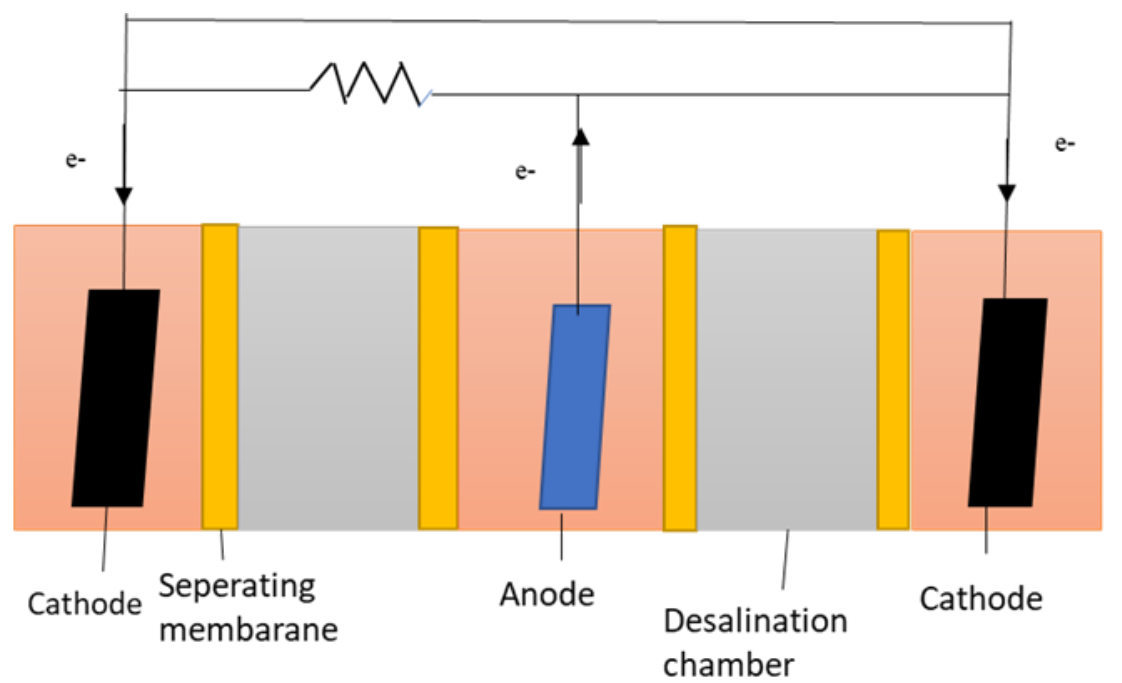

Figure 3. Multi chamber MFC.

\section{Types of catalyst used}

Generally, bacteria are used as catalysts in MFC to oxidize inorganic and organic substance to produce an electric current. But for the production of biohydrogen, coupled Microbial Electrolysis Cell (MEC)-Microbial Fuel Cell (MFC) is used. An external voltage supply must be provided for the Microbial electrolysis cell. Pt is a commonly used catalyst in most of the MFC as it produces high power and also for production of hydrogen in MFC. After removing the pt catalyst, the hydrogen production was stopped. It was reported that if the $\mathrm{Pt}$ catalyst was removed from the cathode in MFC it creates low input voltage in MEC than the original one [47]. Ammonia removal was assisted by the usage of Photo electrocatalysis (PEC) and Microbial Fuel Cells, where low voltage was produce, while a nanocatalyst, $\mathrm{Sn}-\mathrm{V}_{2} \mathrm{O}_{5}$ was used, it enhanced the removal ammonia with efficiency percentage of 99\% [48]. Comparative study between $\mathrm{PbO}$ and $\mathrm{Pt}$ catalyst was done, and $\mathrm{PbO}$ had superior performance than Pt. It is cost-effective and also has many applications [49].

Table 1. Types of Catalysts used.

\begin{tabular}{|c|c|c|}
\hline Catalyst used & Power density & Factors involved \\
\hline Platinum catalyst & $593 \mathrm{~mW} / \mathrm{m}^{2}$ & $\begin{array}{l}\text { Metal porphyrines and phthalocyanines } \\
\text { [52] }\end{array}$ \\
\hline $\begin{array}{l}\text { Iron Pthalocyanin based cathode - } \\
\text { Ketjenblack carbon }\end{array}$ & $634 \mathrm{~mW} / \mathrm{m}^{2}$ & $\begin{array}{l}\text { FePc-KJB as the MFC cathode catalyst } \\
\text { [52]. }\end{array}$ \\
\hline $\begin{array}{l}\text { Anodes and cathode chamber with } \\
\text { Graphite electrode and potassium } \\
\text { ferricyanide catholyte }\end{array}$ & $135.4 \mathrm{~mW} / \mathrm{m}^{2}$ & $\begin{array}{l}\text { Mixed culture of bacteria from distillery } \\
\text { wastewater [46]. }\end{array}$ \\
\hline $\begin{array}{l}\text { Carbon cloth anodes were treated with } \\
\text { phosphate buffer and ammonia gas }\end{array}$ & $1970 \mathrm{~mW} / \mathrm{m}^{2}$ & Mixed Bacteria [53] \\
\hline $\begin{array}{l}\text { Cathode was fabricated by cold } \\
\text { pressing activated carbon with } \\
\text { polytetrafluoroethylene around a } \\
\text { nickel mesh current collector }\end{array}$ & $1220 \mathrm{~mW} / \mathrm{m}^{2}$ & $\begin{array}{l}\text { Activated carbon (AC) air cathode avoided } \\
\text { the metal catalyst [54] }\end{array}$ \\
\hline Platinum catalyst & $1060 \mathrm{~mW} / \mathrm{m}^{2}$ & $\begin{array}{l}\text { Activated carbon (AC) air cathode avoided } \\
\text { the metal catalyst [55] }\end{array}$ \\
\hline $\begin{array}{llr}\text { Activated carbon } & \text { Iron } \\
\text { ethylenediaminetetraacetic } & \text { acid } \\
\begin{array}{l}\text { cathode with stainless steel mesh } \\
\text { current collector }\end{array} & & \end{array}$ & $1580+/-80 \mathrm{~mW} / \mathrm{m}^{2}$ & $\begin{array}{l}\text { Activated carbon (AC) is a cost-effective } \\
\text { catalyst [56]. }\end{array}$ \\
\hline Plain graphite electrodes & $4.31 \mathrm{~W} / \mathrm{m}^{2}$ & $\begin{array}{l}\text { Alcaligenes faecalis and Enterococcus } \\
\text { gallinarum [13]. }\end{array}$ \\
\hline
\end{tabular}


Fuel cell polarisation and other electrochemical studies were performed on non-Pt metal catalysts. From that, it was observed that FePc supported Ketjenblack (KBJ) carbon showed higher oxidation reduction activity than Pt catalysts [50]. Nitrogen and phosphorous doped activated carbon was used as catalyst. It was cheaper compared to the Pt catalyst. But it was observed that the activity of the catalyst was lesser compared with the Pt catalyst but greater than the activated carbon [51]. Different types of catalysts are tabulated below (Table 1).

\section{Uses of MFC}

\subsection{Uses in waste water treatment.}

\subsubsection{Domestic wastewater.}

Domestic wastewater is generally composed of wastes from the human body, laundry, utensil washing, food preparation, etc. and it is mostly turbid and grey in color. The domestic wastewaters are mostly collected from underground pipes. Wastewater must be treated at any cost as the pathogenic microorganisms can grow and multiply and causes major degradation to the environment and health of living creatures. It is always better to treat wastewater before using it for aquaculture or agricultural purposes [57]. While treating it, electricity can also be produced in domestic wastewater using Multiple anode or cathode (MAC) MFC. Among various combinations of cathode materials, $\mathrm{Co}-\mathrm{MnO}_{2}$ cathodes gave the utmost power density of $500 \mathrm{~mW} / \mathrm{m}^{2}$ and also the increased electrode numbers increased the power generation. Jiang et al. [58] used domestic wastewater with activated sludge to generate electrical power using two-chamber (MFC) with graphite cylinder and porous graphite bar as anode and cathode, and the maximum power densities were produced up to $25 \mathrm{mWm}^{-2}$. The factors that affect the working of MFC are GAC (Granular activated carbon) amount, electrode distance, and wastewater substrate concentrations [59]. Domestic wastewater, along with sodium acetate, was subjected as inoculums to achieve the COD concentrations of 100-1500 mg/L. GAC single-chamber microbial fuel cell setup used an expensive platinum-coated carbon cloth as cathode and graphite rod as an anode; the electrode distance was reduced to $2 \mathrm{~cm}$ to increase the output power. They suggested that by increasing the activated carbon power output can also be increased, and the authors observed a maximum power density of $7.2 \mathrm{~W} / \mathrm{m}^{3}$ [60].

\subsubsection{Dairy wastewater.}

Most dairy wastewater can be classified in types like processing, cleaning, and sanitary wastewater. It has been reported that the ratio of dairy wastewater is 2.5 times greater than that of the milk processed. It is said that most of the dairy wastewater comes during the manufacturing process. The released dairy wastewater has an unpleasant odor, and it is mostly white in color. It is unsafe to leave the dairy wastewater untreated as it may show some adverse effects by releasing toxins to the environment that degrades the surroundings [61]. The authors designed a Single chamber MFC with Plain graphite plates as both anode and cathode, and Nafion was used as a membrane. The design used for analyzing the dairy wastewater (DW) treatment for power generation could be developed for Wastewater treatment plants in a large scale. In this approach maximum, volumetric power production was $1.10 \mathrm{~W} / \mathrm{m} 3 ; 308 \mathrm{mV} ; 1.78$ $\mathrm{mA}$. One of the factors concerning the power production was electrode distances, and its value was extremely low, and the system kept continuing [62]. Annular single-chamber MFC was designed with carbon cloth type B and graphite-coated stainless-steel mesh as cathode and 
anode and assumed that the power generation was increased due to the higher surface area of the anode. They took dairy wastewater (COD of $1000 \mathrm{mg} / \mathrm{l}$ ) inoculated by activated sludge from the dairy wastewater treatment plant and produced the utmost power density of $20.2 \mathrm{~W} / \mathrm{m}^{3}$ [63].

\subsubsection{Chemical wastewater.}

In recent days due to the rapid advancement of industrialization and the development of many chemical industries results in the production of more usable chemicals and also chemical wastewater. This chemical wastewater is generally different from another type of wastewater as it affects the whole ecosystems and can sometimes cause permanent changes in living creatures. It has been reported that China ranks first in possessing the chemical industry all over the world. It may release toxins and cause mutations in the human body. So treatment of chemical wastewater is very important for protecting living creatures and human systems [64]. A plain graphite electrode and perforated graphite electrodes were used as cathode and anode in the chemical wastewater treatment plant. Organic loading rates 1 (OLR1) and organic loading rates (OLR2) of $1.165 \mathrm{~kg} \mathrm{COD} / \mathrm{m}^{3}$ day and $1.404 \mathrm{~kg} \mathrm{COD} / \mathrm{m}^{3}$ day respectively were used along with anaerobic mixed consortia for the analysis in a dual chambered MFC design comprised of potassium ferricyanide electrode in phosphate buffer as Cathode, PEM (Nafion 117) as membrane, and the produced voltage and current for OLR2 was $304 \mathrm{mV} \& 6.08 \mathrm{~mA}$ respectively but the method was bit expensive [65]. A simple and inexpensive design was carried out for Chemical wastewater treatment using municipal wastewater treatment plant located locally. The anode and cathode used were non-catalyzed graphite electrodes. They could produce bioelectricity generation up to $631 \mathrm{~mA} / \mathrm{m}^{2}$. This method can be used in waste water treatment plants for its simplicity [66].

\subsubsection{Rice mill wastewater.}

Rice is one of the staple foods. The rice milling industries, are growingly rapidly as it is one of the most important industries, in turn increases the amount of effluent. For the production of rice, the grain is milled, and paraboiled rice requires boiling, which results in the generation of wastewater. It has been reported that nearly 1.2 liters of wastewater are released for paraboiling $1 \mathrm{~kg}$ of rice. By disposing of the wastewater directly into environmental sources like rivers, ponds can cause serious and adverse effects on the environment and causes degradation of resources. So it is advisable to treat the wastewater before further usage [67]. Three different combinations of MFCs have been created for power generation. The anaerobic sludge was inoculated in rice mill wastewater. Two chambers of MFCs, MFC-1 using an earthen pot as membrane and MFC-2 using Proton Exchange Membrane (Nafion), tested at different $\mathrm{pH}$ feeds, and the third MFC was designed with PEM without $\mathrm{pH}$ adjustments. The setup comprised of graphite plates and stainless steel mesh as cathode and anode. They obtained the utmost volumetric power of $2.3 \mathrm{~W} / \mathrm{m}^{3}$ in MFC-1 [68].

\subsubsection{Cassava wastewater.}

Cassava is otherwise called as tapioca. It grows in most depleted soil. It grows automatically without involving the use of any fertilizers or pesticides and can be collected between the time period of 8 to 24 months [69]. Cassava industries are a rich source of producing starch-containing products and produce liquid and soil residues. The liquid residues 
are often taken from the root parts of the plant. Cassava industries use many hazardous chemicals such as cyanide, and it is disposed of in the environment without proper measures. The harmful and pathogenic bacteria can grow in anaerobic conditions by having cyanide as a substrate. The wastewater produced from the cassava industries generally contains methane, which is a hazardous chemical. This results in the depletion of many natural sources and paves the way for an increase in the greenhouse gases [70,71]. To treat this waste water a MFC was designed vertically with $30 \mathrm{~L}$ capacity and having graphite plates as both anode (at the bottom of chamber) and the cathode (at the top). The electrodes were separated from each other using perforated acrylic sheet assisted glass wool. Cassava wastewater with biological treatment occurring in wastewater treatment plant from a cassava mill factory observed the maximum power density upto $18.2 \mathrm{~W} / \mathrm{m}^{2}[72]$.

\subsubsection{Brewery wastewater.}

Brewery wastewater is generally produced due to the continuous heating and cooling process. It has been reported that China is the leading producer of wastewater from brewery industries as it accounts for $1.5 \%$ of the whole world. Generally, brewery wastewater is non toxic as it contains most of the organic matters like sugar, water, and starch [73]. It involves two process brewery and processing mostly the wastewater gets contaminated due to the presence of byproducts generated during this process. The direct disposal of wastewater into natural sources may cause serious problems, which results in the accumulation of bacteria in the natural water bodies [74]. MFC was designed with carbon brushes intertwined with a titanium wire as the anode, and activated carbon served as the cathode. Glass products were used as a membrane for the experimental setup. Brewery wastewater treatment was carried out with a $90 \mathrm{~L}$ capacity MFC, and the power generation was $0.097 \mathrm{~kW} / \mathrm{m}^{3}$ [75].

\subsubsection{Paper plant wastewater.}

As the amount of consumption of paper increases the recycling rate increases, and the wastewater released also increases during the recycling process. The plant wastewater generally consists of cellulose content and also some nonbiodegradable content like some phenolic compounds, which cannot be degraded by normal treatment process [76, 77]. An air cathode design and an ammonia gas treated carbon brush anode were used as electrodes in an MFC. At waterside, cathode contained $0.5 \mathrm{mg} / \mathrm{cm}^{2} \mathrm{Pt}$, and at air side, it contained $30 \mathrm{wt} \%$ wetproofed carbon cloth. Paper-plant wastewater COD: $506 \mathrm{mg} / \mathrm{L}$ and the generated power was $5.9 \pm 0.2 \mathrm{~W} / \mathrm{m}^{3}[78]$

\section{Future Directions}

MFCs provide a sustainable environment for future generations. There are more other updates and upgradation required for making these MFCs to produce continous energy, where usage of low internal resistance, usage of nanoparticles, the inclusion of treated microbial culture, usage of genetically modified organisms can make these MFC work better. The role of mirobial fuel Cells in waste water treatment is well known but the usage of MFC in industrial areas still needs more study and this might possibly increase the performance [79]. Plant assisted MFC can be constructed and it can be used for various other environmental applications like analysing the quality of soil, tracking the plant growth etc. [80]. 


\section{Conclusion}

MFC is a great source of renewable energy. The pollution caused due to industrialization and the usage of Fossil fuels for electricity production is substituted by using this eco- friendly and sustainable method of using MFCs. It produces electricity by converting biological matters using the action of either biocatalysts or enzymes. It is a very efficient system as it uses low internal resistance. It has immense applications for electricity production and wastewater treatment. This system has gained attention due to its production of electricity from organic waste matters in an efficient way, and it remains a promising alternate source for electricity generation with the use of biofuel as a replacement for fossil fuels.

\section{Funding}

This research received no external funding.

\section{Acknowledgments}

This research has no acknowledgment.

\section{Conflicts of Interest}

The authors declare no conflict of interest.

\section{References}

1. Kim, D.H.; Kim, S.H.; Shin, H.S. Sodium inhibition of fermentative hydrogen production. Int $j$ hydrogen energ 2009, 34, 3295-3304, https://doi.org/10.1016/j.ijhydene.2009.02.051.

2. Reungsang, A.; Saripan, A.F. Biohydrogen production by Thermoan aerobacterium thermosaccharolyticum KKU-ED1: Culture conditions optimization using mixed xylose/arabinose as substrate. Electron j biotechn 2013, 16, https://doi.org/10.2225/vol16-issue1-fulltext-1.

3. Levin, D. B.; Pitt, L.; Love, M. Biohydrogen production: Prospects and limitations to practical application. Int $j$ hydrogen energ 2004, 29, 173-185, https://doi.org/10.1016/S0360-3199(03)00094-6.

4. Shaoan, C.; Bruce, E.L. Ammonia treatment of carbon cloth anodes to enhance power generation of microbial fuel cells. Electrochem. Commun 2007, 9, 492-496, https://doi.org/10.1016/j.elecom.2006.10.023.

5. Bai, L.; Zhou; M.; Gu. C. Advanced nanomaterials for the design and construction of anode for microbial fuel cells. Advanced electrode materials 2016, 457-483, https://doi.org/10.1002/9781119242659.ch12.

6. Cheng, S.; Liu; H.; Logan, B. E. Increased performance of single-chamber microbial fuel cells using an improved cathode structure. Electrochem. commun. 2006, 8, 489-494.

7. Rabaey, K.; Clauwaert, P.; Aelterman, P.; Verstraete, W. Tubular microbial fuel cells for efficient electricity generation. Environ. Sci. 2005, 39, 8077-8082, https://doi.org/10.1021/es050986i.

8. Jang, J.K.; Pham, T.H.; Chang, I.S.; Kang, K.H.; Moon, H.; Cho, K.S.; Kim, B.H. Construction and operation of a novel mediator-and membrane-less microbial fuel cell. Process biochem. 2004, 39, 1007-1012, https://doi.org/10.1016/S0032-9592(03)00203-6.

9. He, Z.; Minteer, S.D.; Angenent, L.T. Electricity generation from artificial wastewater using an upflow microbial fuel cell. Environ. Sci. Technol. 2005, 39, 5262-5267, https://doi.org/10.1021/es0502876.

10. Wei, J.; Liang, P.; Huang, X. Recent progress in electrodes for microbial fuel cells. Bioresour. Technol. 2011, 102, 9335-9344, https://doi.org/10.1016/j.biortech.2011.07.019.

11. Logan, B.E. Scaling up microbial fuel cells and other bioelectrochemical systems. Appl microbiol biot. 2010, 85, 1665-1671, https://doi.org/10.1007/s00253-009-2378-9.

12. Kim, B.H.; Ikeda, T.; Park, H.S.; Kim, H.J.; Hyun, M.S.; Kano, K.; Tatsumi, H. Electrochemical activity of an Fe (III)-reducing bacterium, Shewanella putrefaciens IR-1, in the presence of alternative electron acceptors. Biotechnol. Tech. 1999, 13, 475-478, https://doi.org/10.1023/A:1008993029309.

13. Rabaey, K.; Boon, N.; Siciliano, S.D.; Verhaege, M.; Verstraete, W. Biofuel cells select for microbial consortia that self-mediate electron transfer. Appl. Environ. Microbiol. 2004, 70, 5373-5382, https://doi.org/10.1128/aem.70.9.5373-5382.2004.

14. Mohan, S.V.; Saravanan, R.; Raghavulu, S.V.; Mohanakrishna, G.; Sarma, P.N. Bioelectricity production from wastewater treatment in dual chambered microbial fuel cell (MFC) using selectively enriched mixed 
microflora: effect of catholyte. Bioresour. Technol. 2008, 99, 596-603, https://doi.org/10.1016/j.biortech.2006.12.026

15. Oh, S.; Logan, B.E. Electricity generation using an air catode single chamber microbial fuel cell in the presence and absence of a proton exchange membrane. Environ. Sci. Technol 2004, 38, 4040-4046, https://doi.org/10.1021/es0499344.

16. Shahi, A.; Rai, B.N.; Singh, R.S. A comparative study of a bio fuel cell with two different proton exchange membrane for the production of electricity from waste water. Resource-Efficient Technologies 2017, 3, 7881, https://doi.org/10.1016/j.reffit.2017.01.006.

17. Nagesh, M.; Senthilkumar, P.; Jenifer Selvarani, A.; Raji, P.; Kasipandian, K.; Ponnaiah, P.; Thirumurugan, R. Electricity Generation using Carboxymethyl Cellulose and Kitchen Waste as Substrate by Exiguobacterium sp SU-5 in Mediatorless Microbial Fuel Cell. J Pure Appl Microbiol. 2019, 13, 2151-2158, https://doi.org/10.22207/JPAM.13.4.27.

18. Drisya, C.M.; Manjunath, N.T. Dairy Wastewater Treatment and Electricity Generation Using Microbial Fuel Cell. Int Res J Eng Technol. 2017, 4, 1293-1296.

19. Paraksh, A.; Aziz, S.; Nazir, I.; Soomro, S.A. Utilizing dairy wastewater for electricity generation using environment-friendly double chambered microbial fuel cell. Paraksh 2016, 8, 44-50.

20. Samrot, A.V.; Paulraj, P.; Petchi, I.; Nagesh, M.; Selvarani A.J.; Kasipandian, K. Electricity Generation in Mediatorless Microbial Fuel Cell Using Agrobacterium Tumefaciens Su-11 Having Lactose and Dairy Waste As Carbon Source. Int. J. Adv. Res. in Eng. and Tech. 2019, 10, 89-95.

21. Rismani-Yazdi, H.; Carver, S.M.; Christy, A.D.; Tuovinen, O.H. Cathodic limitations in microbial fuel cells: an overview. J Power Sources 2008, 180, 683-694, https://doi.org/10.1016/j.jpowsour.2008.02.074.

22. Li, M.; Zhou, S.; Xu, M. Graphene oxide supported magnesium oxide as an efficient cathode catalyst for power generation and wastewater treatment in single chamber microbial fuel cells. Chem. Eng. 2017, 328, 106-116, https://doi.org/10.1016/j.cej.2017.07.031.

23. Liu, H.; Cheng, S.; Huang, L.; Logan, B.E. Scale-up of membrane-free single-chamber microbial fuel cells. J. Power Sources. 2008, 179, 274-279, https://doi.org/10.1016/j.jpowsour.2007.12.120.

24. Bond, D.R.; Lovley, D.R. Electricity production by Geobacter sulfurreducens attached to electrodes. Appl. Environ. Microbiol. 2003, 69, 1548-1555, https://doi.org/10.1128/AEM.69.3.1548-1555.2003.

25. Park, D.H.; Zeikus, J.G. Improved fuel cell and electrode designs for producing electricity from microbial degradation. Biotechnol. Bioeng. 2003, 81, 348-355, https://doi.org/10.1002/bit.10501.

26. Oh, S.; Min, B.; Logan, B.E. Cathode performance as a factor in electricity generation in microbial fuel cells. Environ. Sci. Technol. 2004, 38, 4900-4904, https://doi.org/10.1021/es049422p.

27. Clauwaert, P.; Van der Ha, D.; Boon, N.; Verbeken, K.; Verhaege, M.; Rabaey, K.; Verstraete, W. Open air biocathode enables effective electricity generation with microbial fuel cells. Environ. Sci. Technol. 2007, 41, 7564-7569, https://doi.org/10.1021/es0709831.

28. Huang, L.; Chai, X.; Chen, G.; Logan, B.E. Effect of set potential on hexavalent chromium reduction and electricity generation from biocathode microbial fuel cells. Environ Sci Technol. 2011, 45, 5025-5031, https://doi.org/10.1021/es103875d.

29. Call, T.P.; Carey, T.; Bombelli, P.; Lea-Smith, D.J.; Hooper, P.; Howe, C.J.; Torrisi, F. Platinum-free, graphene based anodes and air cathodes for single chamber microbial fuel cells. J. Materials Chemistry A 2017, 5, 23872-23886, https://doi.org/10.1039/C7TA06895F.

30. Song, X.; Liu, J.; Jiang, Q.; Qu, Y.; He, W.; Logan, B.E.; Feng, Y. Enhanced electricity generation and effective water filtration using graphene-based membrane air-cathodes in microbial fuel cells. J. Power Sources 2018, 395, 221-227, https://doi.org/10.1016/j.jpowsour.2018.05.043.

31. Zhang, L.; Wang, J.; Fu, G.; Zhang, Z. Simultaneous electricity generation and nitrogen and carbon removal in single-chamber microbial fuel cell for high-salinity wastewater treatment. J. Clean. Prod. 2020, 123-203, https://doi.org/10.1016/j.jclepro.2020.123203.

32. Kim, J.R.; Jung, S.H.; Regan, J.M.; Logan, B.E. Electricity generation and microbial community analysis of alcohol powered microbial fuel cells. Bioresour. Technol. 2017, 98, 2568-2577, https://doi.org/10.1016/j.biortech.2006.09.036.

33. Liu, H.; Logan, B.E. Electricity generation using an air-cathode single chamber microbial fuel cell in the presence and absence of a proton exchange membrane. Environ. Sci. Technol. 2004, 38, 4040-4046, https://doi.org/10.1021/es0499344.

34. Watanabe, K. Recent developments in microbial fuel cell technologies for sustainable bioenergy. $J$ biosci bioeng. 2008, 106, 528-536, https://doi.org/10.1263/jbb.106.528.

35. Liu, H.; Cheng, S.; Logan, B.E. Production of electricity from acetate or butyrate using a single-chamber microbial fuel cell. Environ. Sci. Technol. 2005, 39, 658-662, https://doi.org/10.1021/es048927c.

36. Pandit, S.; Ghosh, S.; Ghangrekar, M.M.; Das, D. Performance of an anion exchange membrane in association with cathodic parameters in a dual chamber microbial fuel cell. Int $j$ hydrogen energ. 2012, 37, 9383-9392, https://doi.org/10.1016/j.ijhydene.2012.03.011.

37. Almatouq, A.; Babatunde, A.O. Identifying optimized conditions for concurrent electricity production and phosphorus recovery in a mediator-less dual chamber microbial fuel cell. Appl. Energy 2018, 230, 122-134, https://doi.org/10.1016/j.apenergy.2018.08.108. 
38. Penteado, E.D.; Fernandez-Marchante, C.M.; Zaiat, M.; Gonzalez, E.R.; Rodrigo, M.A. Influence of carbon electrode material on energy recovery from winery wastewater using a dual-chamber microbial fuel cell. Environ. Technol. 2017, 38, 1333-1341, https://doi.org/10.1080/09593330.2016.1226961.

39. Huang, L.; Cheng, S.; Rezaei, F.; Logan, B.E. Reducing organic loads in wastewater effluents from paper recycling plants using microbial fuel cells. Environ Technol. 2009, 30, 499-504, https://doi.org/10.1080/09593330902788244.

40. Xia, X.; Tokash, J.C.; Zhang, F.; Liang, P.; Huang, X.; Logan, B.E. Oxygen reducing biocathodes operating with passive oxygen transfer in microbial fuel cells. Environ Sci Technol. 2013, 47, 2085-2091, https://doi.org/10.1021/es3027659.

41. Tandukar, M.; Huber, S.J.; Onodera, T. Pavlostathis S. Biological chromium(VI) reduction in the cathode of a microbial fuel cell. Environ Sci Technol. 2009, 43, 8159-8165, https://doi.org/10.1021/es9014184.

42. Rhoads, A.; Beyenal, H.; Lewandowski, A.; Huber, S.J.; Onodera, T.; Pavlostathis, S.G. Microbial fuel cell using anaerobic respiration as an anodic reaction and biomineralized manganese as a cathodic reactant. Environ Sci Technol. 2009, 43, 8159-8165, https://doi.org/10.1021/es048386r.

43. Zhang, S.; Bao, R.; Lu, J.; Sang, W. Simultaneous sulfide removal, nitrification, denitrification and electricity generation in three-chamber microbial fuel cells. Sep. Purif. Technol. 2018, 195, 314-321, https://doi.org/10.1016/j.seppur.2017.12.027.

44. Zhao, Q.; Yu, H.; Zhang, W.; Kabutey, F.T.; Jiang, J.; Zhang, Y.; Wang, K.; Ding, J. Microbial fuel cell with high content solid wastes as substrates: a review. Frontiers of Environmental Science \& Engineering 2017, 11, https://doi.org/10.1007/s11783-017-0918-6.

45. Zhang, G.; Zhao, Q.; Jiao, Y.; Wang, K.; Lee D.-J; Ren, N. Efficient electricity generation from sewage sludge using biocathode microbial fuel cell. Water Res. 2012, 46, 43-52, https://doi.org/10.1016/j.watres.2011.10.036.

46. Samsudeen, N.; Sharma, A.; Radhakrishnan, T K.; Matheswaran, M. Performance investigation of multichamber microbial fuel cell: an alternative approach for scale up system. IOP Conference Series: Materials Science and Engineering 2015, 7, https://doi.org/10.1088/1757-899X/330/1/012034.

47. Sun, M.; Sheng, G.-P.; Zhang, L.; Xia, C.-R.; Mu, Z.-X.; Liu, X.-W.; Wang, H.-L.; Yu, H.-Q.; Qi, R.; Yu, T.; Yang, M. An MEC-MFC-coupled system for biohydrogen production from acetate. Environ. Sci. Technol. 2008, 42, 8095-8100. https://doi.org/10.1021/es801513c.

48. Yan, C.; Liu, L. Sn-doped V2O5 nanoparticles as catalyst for fast removal of ammonia in air via PEC and PEC-MFC. Chem. Eng. 2020, 392, https://doi.org/10.1016/j.cej.2019.123738.

49. Morris, J.M.; Jin, S.; Wang, J.; Zhu, C.; Urynowicz, M.A. Lead dioxide as an alternative catalyst to platinum in microbial fuel cells. Electrochem. commun. 2007, 9, 1730-1734, https://doi.org/10.1016/j.elecom.2007.03.028.

50. HaoYu, E.; Cheng, S.; Scott, K.; Logan, B. Microbial fuel cell performance with non-Pt cathode catalysts. J. power sources, 2007, 171, 275-281, https://doi.org/10.1016/j.jpowsour.2007.07.010.

51. Liu, T.; Jean Pierre, M.; Li, H.; Wu, W.; Tu, M.; Wang, Q.; Ma, H. Nitrogen and Phosphorus Doped Activated Carbon Catalyst Prepared from Shrimp Shell and its Application in MFC Air Cathode. ChemistrySelect 2020, 5, 2690-2695, https://doi.org/10.1002/slct.201904894.

52. HaoYu, E., Cheng, S., Scott, K., \& Logan, B. (2007). Microbial fuel cell performance with non-Pt cathode catalysts. Journal of power sources, 171(2), 275-281.

53. Cheng, S., \& Logan, B. E. (2007). Ammonia treatment of carbon cloth anodes to enhance power generation of microbial fuel cells. Electrochemistry Communications, 9(3), 492-496.

54. Zhang, F., Cheng, S., Pant, D., Van Bogaert, G., \& Logan, B. E. (2009). Power generation using an activated carbon and metal mesh cathode in a microbial fuel cell. Electrochemistry Communications, 11(11), 21772179.

55. Bhargavi, G., Venu, V., \& Renganathan, S. (2018, March). Microbial fuel cells: recent developments in design and materials. In IOP Conference Series: Materials Science and Engineering (Vol. 330, No. 1).

56. Xia, X., Zhang, F., Zhang, X., Liang, P., Huang, X., \& Logan, B. E. (2013). Use of pyrolyzed iron ethylenediaminetetraacetic acid modified activated carbon as air-cathode catalyst in microbial fuel cells. ACS applied materials \& interfaces, 5(16), 7862-7866.

57. Mara, D. Domestic wastewater treatment in developing countries. Routledge, 2013.

58. Jiang, D.; Curtis, M.; Troop, E.; Scheible, K.; McGrath, K.; Hu, B.; Suib, S.; Raymond, D.; Li, B. A pilotscale study on utilizing multi-anode/cathode microbial fuel cells (MAC MFCs) to enhance the power production in wastewater treatment. Int $J$ Hydrogen Energy 2011, 36, 876-884, https://doi.org/10.1016/j.ijhydene.2010.08.074.

59. Rodrigo, M.A.; Cãnizares, P.; Lobato, J.; Paz, R.; Saez, C.; Linares, JJ. Production of electricity from the treatment of urban waste water using a microbial fuel cell. J Power Sources 2007, 169, 198-204, https://doi.org/10.1016/j.jpowsour.2007.01.054.

60. Jiang, D.; Li, B. Granular activated carbon single-chamber microbial fuel cells (GAC-SCMFCs): a design suitable for large-scale wastewater treatment processes. Biochem Eng J. 2009, 47, 31-37, https://doi.org/10.1016/j.bej.2009.06.013. 
61. Kolev Slavov, A. General characteristics and treatment possibilities of dairy wastewater-a review. Food Technol. 2017, 55, 14-28, https://doi.org/10.17113/ftb.55.01.17.4520.

62. Venkata Mohan, S.; Mohanakrishna, G.; Velvizhi, G.; Lalit Babu, V.; Sarma, P.N. Bio-catalyzed electrochemical treatment of real field dairy wastewater with simultaneous power generation. Biochem Eng J. 2010, 51, 32-39, https://doi.org/10.1016/j.bej.2010.04.012.

63. Mardanpour, M.M.; Nasr Esfahany, M.; Behzad T.; Sedaqatvand, R. Single chamber microbial fuel cell with spiral anode for dairy waste water treatment. Biosens Bioelectron 2012, 38, 264-269, https://doi.org/10.1016/j.bios.2012.05.046.

64. Kong, Z.; Li, L.; Xue, Y.; Yang, M.; Li, Y.Y. Challenges and prospects for the anaerobic treatment of chemical-industrial organic wastewater: a review. J. Clean. Prod. 2019, 231, 913-927, https://doi.org/10.1016/j.jclepro.2019.05.233.

65. Mohan, S.V.; Mohanakrishna, G.; Reddy, B.P.; Saravanan, R; Sarma, P.N. Bioelectricity generation from chemical wastewater treatment in mediatorless (anode) microbial fuel cell (MFC) using selectively enriched hydrogen producing mixed culture under acidophilic microenvironment. Biochem Eng J. 2008, 39, 121-130, https://doi.org/10.1016/j.bej.2007.08.023.

66. Velvizhi, G.; Goud, R.K.; Mohan, S.V. Anoxic bioelectrochemical system for treatment of complex chemical wastewater with simultaneous bioelectricity generation. Bioresour Technol. 2014, 151, 214-220, https://doi.org/10.1016/j.biortech.2013.10.028.

67. Kumar, A.; Priyadarshinee, R.; Roy, A.; Dasgupta, D.; Mandal, T. Current techniques in rice mill effluent treatment: Emerging opportunities for waste reuse and waste-to-energy conversion. Chemosphere 2016, 164, 404-412, https://doi.org/10.1016/j.chemosphere.2016.08.118.

68. Behera, M.; Jana, P.S.; More, T.T.; Ghangrekar, M.M. Rice mill wastewater treatment in microbial fuel cells fabricated using proton exchange membrane and earthen pot at different pH. Bioelectrochem. 2010, 79, 228233, https://doi.org/10.1016/j.bioelechem.2010.06.002.

69. Okudoh, V.; Trois, C.; Workneh, T.; Schmidt, S. The potential of cassava biomass and applicable technologies for sustainable biogas production in South Africa: A review. Renew. Sust. Energ. Rev. 2014, 39, 1035-1052, https://doi.org/10.1016/j.rser.2014.07.142.

70. Kuczman, O.; Tavares, M.H.F.; Gomes, S.D.; Guedes, L.P.C.; Grisotti, G. Effects of stirring on cassava effluent treatment in an anaerobic horizontal tubular pilot reactor with support medium-A Review. Renew. Sust. Energ. Rev. 2017, 77, 984-989, https://doi.org/10.1016/j.rser.2016.11.238.

71. Barana, A.C.; Cereda, M.P. Cassava wastewater (manipueira) treatment using a two-phase anaerobic biodigestor. Lwt-food sci technol. 2000, 20, 183-186, https://doi.org/10.1590/S0101-20612000000200010.

72. Kaewkannetra, P.; Chiwes, W.; Chiu, T.Y. Treatment of cassava mill wastewater and production of electricity through microbial fuel cell technology. Fuel. 2011, 90, 2746-2750, https://doi.org/10.1016/j.fuel.2011.03.031.

73. Feng, Y.; Wang, X.; Logan, B.E.; Lee, H. Brewery wastewater treatment using air-cathode microbial fuel cells. Appl microbiol biot. 2008, 78, 873-880, https://doi.org/10.1007/s00253-008-1360-2.

74. Simate, G.S.; Cluett, J.; Iyuke, S.E.; Musapatika, E.T.; Ndlovu, S.; Walubita, L.F.; Alvarez, A.E. The treatment of brewery wastewater for reuse: State of the art. Desalination 2011, 273, 235-247, https://doi.org/10.1016/j.desal.2011.02.035.

75. Dong, Y.; Qu, Y.; He, W.; Du, Y.; Liu, J.; Han, X.; Feng, Y. A 90-liter stackable baffled microbial fuel cell for brewery wastewater treatment based on energy self-sufficient mode. Bioresour. Technol. 2015, 195, 6672, https://doi.org/10.1016/j.biortech.2015.06.026.

76. Huang, L.; Logan, B.E. Electricity generation and treatment of paper recycling wastewater using a microbial fuel cell. Appl microbiol biot. 2008, 80, 349-355, https://doi.org/10.1007/s00253-008-1546-7.

77. Buyukkamaci, N.; Koken, E. Economic evaluation of alternative wastewater treatment plant options for pulp and paper industry. Sci total environ. 2010, 408, 6070-6078, https://doi.org/10.1016/j.scitotenv.2010.08.045.

78. Huang, L.; Cheng, S.; Rezaei, F.; Logan, B.E. Reducing organic loads in wastewater effluents from paper recycling plants using microbial fuel cells. Environ Technol. 2009, 30, 499-504, https://doi.org/10.1080/09593330902788244.

79. Srivastava, P.; Yadav, A. K.; Garaniya, V.; Abbassi, R. Constructed wetland coupled microbial fuel cell technology: development and potential applications. MET. 2019, 1021-1036. Elsevier. https://doi.org/10.1016/B978-0-444-64052-9.00042-X.

80. Regmi, R.; Nitisoravut, R.; Ketchaimongkol, J. A decade of plant-assisted microbial fuel cells: looking back and moving forward. Biofuels, 2018, 9, 605-612. https://doi.org/10.1080/17597269.2018.1432272. 